\title{
GANGGUAN PERTUMBUHAN DAN DEFISIT BERAT BADAN PADA BALITA DI PERKOTAAN DAN PEDESAAN
}

\author{
Sri Muljati'; Dwi Hapsari ${ }^{2}$ dan Basuki Budiman ${ }^{1}$ \\ ${ }^{1}$ Pusat Penelitian dan Pengembangan Gizi, Badan Litbang Kesehatan Dep Kes \\ ${ }^{2}$ Badan Litbang Kesehatan Dep Kes
}

\section{ABSTRACT \\ GROWTH FAILURE AND BODY WEIGHT DEFICIT OF UNDERFIVE CHILDREN IN URBAN AND RURAL AREAS}

The prevalence of malnutrition in Indonesia in 2003 is 19 percents; three percents of them are severe malnutrition. Study on the age beginning deviation of growth failure and the extent of the deficit in body weight of underfive children in Indonesia is scarce. We analysed 1694 records of children underfive year old from National Household Survey (SKRT) having complete data in weight, height and age. The study revealed that $42.9 \%$ children underfives suffered from growth failure, in which the magnitude was greater in rural than urban e.i. $53.8 \%$ and $46.2 \%$ respectively growth failure started. In the age 4 months, infant begins deficit his her body weight and the peak of the deficit is infant in six months e.i $21.05 \%$. This analysis supports international finding that deviation in growth failure begin at 4 month for Indonesian children should be considered

Keywords: under five year children, growth

\section{PENDAHULUAN}

$\mathrm{M}$ asalah gangguan pertumbuhan pada anak usia di bawah lima tahun (balita) di Indonesia cukup serius karena salah satu konsekuensi gangguan gizi pada usia balita adalah gangguan pertumbuhan. Hal ini ditunjukkan dengan prevalensi gizi buruk dan gizi kurang yang masih tinggi.

Data Departemen kesehatan 2003 (1) menunjukkan bahwa pada kelompok usia balita di Indonesia prevalensi gizi kurang sebesar $19 \%$ dan gizi buruk $3 \%$. Status gizi anak usia balita berdampak pada kualitas sumberdaya manusia. Kurang gizi pada anak balita akan mengakibatkan gangguan pertumbuhan panjang badan sekitar $10 \mathrm{~cm}$, berat badan $2 \mathrm{~kg}$ pada usia sekolah dan hambatan mental berpotensi turun sampai 10 poin serta meningkatkan anemia dan kematian anak (2). Indeks Pembangunan Manusia atau HDI (Human development indeks) Indonesia tahun 2002 adalah 110 dari 179 negara.

Pertumbuhan adalah perubahan ukuran fisik dari waktu ke waktu. Ukuran fisik merupakan ukuran tubuh manusia baik dari segi dimensi, proporsi maupun komposisinya dan lebih dikenal dengan sebutan antropometri. Oleh karena pertumbuhan merupakan suatu proses yang berkelanjutan dan mengikuti perjalanan waktu maka pertumbuhan pada manusia dapat diartikan pula sebagai perubahan antropometri dari waktu ke waktu. Ciri pertumbuhan;1) merupakan perubahan yang dapat diukur secara kuantitatif, 2) mengikuti perjalanan waktu, 3) dalam keadaan normal memiliki jalur tertentu untuk setiap anak (Growth Trajectory). (3)

Penurunan arah garis pertumbuhan sudah dianggap sebagai suatu hal yang tidak normal, sekalipun anak tersebut masih meningkat berat badannya. (4) Penyebab langsung terjadinya gagal tumbuh pada balita adalah sinergisme konsumsi makanan yang kurang dan penyakit infeksi 
Di samping itu banyak faktor lain yang ikut berpengaruh terhadap gangguan pertumbuhan pada balita. Kajian tentang pendidikan, pekerjaan ayah dan ibu kemudian umur anak dan pendapatan keluarga per bulan terhadap gangguan pertumbuhan pada kelompok usia balita diungkap dalam tulisan ini dan berapa besarnya defisit berat badan pada balita yang mengalami gangguan pertumbuhan di pedesaan dan perkotaan.

\section{BAHAN DAN CARA}

Tulisan ini merupakan hasil analisis lanjut dari data SKRT tahun 2004. Subyek dalam analisis ini adalah balita terakhir rumah tangga yang menjadi sampel dalam Survei Kesehatan Rumah Tangga (SKRT) tahun 2004, memiliki hubungan ayah dengan kepala keluarga dan memiliki hubungan ibu dengan pasangan kepala keluarga. Jumlah data keseluruhan sebanyak 1728 anak balita, namun yang dapat disertakan dalam analisis sebanyak 1694 balita yaitu yang memiliki data panjang badan dan berat badan secara lengkap. Penjelasan tentang SKRT, desain, cara pengambilan sampel dan pengumpulan data dapat dipelajari dalam buku Survei Kesehatan Rumah Tangga, volume 1 (SKRT, 2004) (5).

Penyakit infeksi dan status gizi saling mempengaruhi. Namun karena keterbatasan data, informasi penyakit infeksi dan konsumsi tidak disertakan dalam analisis ini. Pendidikan, pekerjaan dan umur orang tua, jumlah anggota rumah tangga, jumlah balita, nomor urut anak, jenis kelamin, umur subyek serta pendapatan keluarga per bulan secara tidak langsung dapat mempengaruhi pertumbuhan pada balita merupakan variabel bebas dalam analisis ini. Pertumbuhan sebagai variabel terikat dibuat dalam dua katagori yaitu ( 0 bila tidak ada gangguan pertumbuhan dan 1 bila ada gangguan pertumbuhan).
Indeks antropometri yang digunakan adalah berat badan menurut menurut tinggi badan (BB/TB) WHO NCHS, karena indeks BB/TB dapat digunakan untuk menentukan status gizi saat kini. Subyek dinyatakan mengalami gangguan pertumbuhan bila berat badan yang dicapai subyek saat pengumpulan data lebih rendah bila dibandingkan dengan berat badan normal subyek yang sesuai dengan tinggi badan pada nilai Z-skor $-1 \mathrm{SD}$. Bila di plot dalam Kartu Menuju Sehat berada dibawah jalur pertumbuhan normalnya

Persentase defisit berat badan adalah selisih berat badan saat pengumpulan data dengan berat badan acuan subyek kemudian dibagi berat badan acuan tersebut dan hasilnya dikalikan $100 \%$.

Penentuan katagori miskin menggunakan batas kemiskinan Rp.108725 untuk pedesaan dan Rp. 143455 perkotaan dari pendapatan perkapita per bulan sesuai ketentuan Biro Pusat Statistik 2004.

Analisis dilakukan secara univariat dan bivariat.

\section{HASIL}

Subyek umumnya berasal dari rumah tangga dengan jumlah anggota keluarga sebanyak empat orang (Tabel 1) dan jumlah orang dewasa dalam keluarga sebanyak dua orang. Subyek umumnya berasal dari rumah tangga yang memiliki satu orang balita namun masih ditemukan rumah tangga dengan jumlah balita sebanyak tiga orang. Umur subyek dihitung berdasarkan bulan, rerata berumur 29 bulan, termuda berumur satu bulan dan tertua 59 bulan, subyek lakilaki $53.4 \%$ dan $46.6 \%$ perempuan. Subyek berasal dari rumah tangga dengan median pengeluaran per kapita per bulan sebesar Rp.159349,-.Umur kepala keluarga rerata 35 tahun sedangkan rerata umur pasangannya/ istri adalah 30 tahun. 
Tabel 1

Gambaran umum balita dan keluarga

\begin{tabular}{|l|c|c|c|c|c|c|}
\hline \multicolumn{1}{|c|}{ Nama variabel } & Mean & Median & SD & Modus & Minimum & Maximum \\
\hline Anggota rumahtangga & 4,6 & 4 & \pm 1.49 & 4 & 2 & 13 \\
Anggota rumahtangga dws & 2.28 & 2 & \pm 0.64 & 2 & 1 & 7 \\
Urutan kelahiran & 2.38 & 2 & \pm 1.35 & 2 & 1 & 12 \\
Jumlah balita & 1.2 & 1 & \pm 0.53 & 1 & 1 & 3 \\
Umur balita (bulan) & 29.43 & 29 & \pm 13.7 & 36 & 1 & 59 \\
Pendapan perkapita/bulan & 192216,3 & 159349 & \pm 129.9 & 77811,6 & 27585,1 & $2622261^{*}$ \\
Umur kepala keluarga (th)) & 35.56 & 35.0 & \pm 7.3 & 35.0 & 18 & 69 \\
Umur pasangan/istri (th) & 30.72 & 30.0 & \pm 6.4 & 30 & 15 & 64 \\
\hline
\end{tabular}

${ }^{*}$ Satuan dalam rupiah

Berdasarkan pekerjaan kepala keluarga sebanyak $51.3 \%$ memiliki usaha sendiri, $37.25 \%$ bekerja sebagai buruh/karyawan. Sedangkan yang lainnya sebanyak $10.1 \%$ sebagai pekerja bebas dan $2.7 \%$ tidak memiliki pekerjaan.

Sebahagian besar ibu subyek $68.6 \%$ tidak bekerja, $10.3 \%$ melakukan usaha sendiri, $7.7 \%$ sebagai buruh/karyawan dan $13.4 \%$ pekerja bebas.

Pendidikan formal sebagian besar kepala keluarga $51.7 \%$ memiliki pendidikan SD dan SMP, $32.0 \%$ SMA+ dan $16.3 \%$ tidak sekolah/tidak tamat SD. Hal yang sama ditemukan pada pendidikan pasangannya, SD dan SMP yaitu 58.9\%. pendidikan SMA + $23.75 \%$ lebih banyak dari pada kepala keluarga.

Setelah dilakukan penilaian terhadap pertumbuhan yang dicapai subyek sebanyak $57.1 \%$ masih berada pada jalur pertumbuhan normal dan $42.9 \%$ berada di bawah jalur pertumbuhan normal. Subyek yang berada di bawah jalur pertumbuhan normal sebanyak $46.2 \%$ berada di perkotaan dan $53.8 \%$ di pedesaan. Jadi sebagian besar subyek yang berada di bawah jalur pertumbuhan normal berada di pedesaan.

Menurut lokasi tempat tinggal sebanyak $48.5 \%$ subyek bertempat tinggal di perkotaan dan $51.5 \%$ di pedesaaan.

Berdasarkan status ekonomi subyek $37.1 \%$ subyek termasuk katagori kaya dan $62.9 \%$ termasuk katagori miskin. Sebahagian besar subyek berasal dari rumah tangga yang termasuk katagori miskin yaitu $62.9 \%$ dan sebanyak $82.0 \%$ keluarga miskin berada di pedesaan.

Lebih lanjut ditemukan bahwa sebanyak $7.1 \%$ subyek berasal dari rumah tangga yang memiliki ibu berumur 21 tahun atau lebih muda dan $63.5 \%$ dari ibu muda tersebut termasuk katagori miskin. Kemudian dari 121 pasangan (istri) yang berumur 21 tahun atau lebih muda tesebut ditemukan $77.2 \%$ berpendidikan Sekolah Dasar atau Sekolah Menengah Pertama, 14.9\% tidak sekolah atau Sekolah Dasar tidak tamat dan 7.9\% Sekolah Menengah Atas atau lebih tinggi (Tabel 2). 
Tabel 2

Proporsi balita menurut sosiodemografi

\begin{tabular}{|c|c|c|}
\hline Nama variable & $\mathrm{N}$ & $\%$ \\
\hline $\begin{array}{l}\text { Jenis kelamin } \\
\text { Laki-laki } \\
\text { Perempuan }\end{array}$ & $\begin{array}{l}904 \\
790\end{array}$ & $\begin{array}{l}53.4 \\
46.6\end{array}$ \\
\hline $\begin{array}{l}\text { Pekerjaan kepala keluarga } \\
\text { Tidak bekerja } \\
\text { Usaha sendiri } \\
\text { Buruh/ karyawan/pegawai } \\
\text { Pekerja bebas }\end{array}$ & $\begin{array}{l}46 \\
860 \\
622 \\
166\end{array}$ & $\begin{array}{l}2.7 \\
51.3 \\
37.4 \\
10.1\end{array}$ \\
\hline $\begin{array}{l}\text { Pekerjaan pasangan (istri) } \\
\text { Tidak bekerja } \\
\text { Usaha sendiri } \\
\text { Buruh/ karyawan/pegawai } \\
\text { Pekerja bebas }\end{array}$ & $\begin{array}{l}1162 \\
175 \\
130 \\
227\end{array}$ & $\begin{array}{c}68.6 \\
10.3 \\
7.7 \\
13.4\end{array}$ \\
\hline $\begin{array}{l}\text { Pendidikan kepala keluaga } \\
\text { Tidak sekolah/Tidak tamat SD } \\
\text { SD-SMP } \\
\text { SMA + }\end{array}$ & $\begin{array}{l}275 \\
876 \\
543\end{array}$ & $\begin{array}{l}16.3 \\
51.7 \\
32.0\end{array}$ \\
\hline $\begin{array}{l}\text { Pendidikan pasangan (istri) } \\
\text { Tidak sekolah/Tidak tamat SD } \\
\text { SD-SMP } \\
\text { SMA + }\end{array}$ & $\begin{array}{l}295 \\
997 \\
401\end{array}$ & $\begin{array}{l}17.4 \\
58.9 \\
23.7\end{array}$ \\
\hline $\begin{array}{l}\text { Berat badan } \\
\text { Normal } \\
\text { defisit } \\
\end{array}$ & $\begin{array}{l}968 \\
726\end{array}$ & $\begin{array}{l}57.1 \\
42.9\end{array}$ \\
\hline $\begin{array}{c}\text { Tempat tinggal } \\
\text { Perkotaan } \\
\text { Pedesaan }\end{array}$ & $\begin{array}{l}821 \\
873\end{array}$ & $\begin{array}{l}48.5 \\
51.5\end{array}$ \\
\hline $\begin{array}{l}\text { Status ekonomi } \\
\text { Kaya } \\
\text { Miskin }\end{array}$ & $\begin{array}{c}629 \\
1065\end{array}$ & $\begin{array}{l}37.1 \\
62.9\end{array}$ \\
\hline $\begin{array}{l}\text { Umur kepala keluarga } \\
\leq 25 \text { tahun } \\
>25 \text { tahun }\end{array}$ & $\begin{array}{r}67 \\
1627\end{array}$ & $\begin{array}{c}4.0 \\
96.0\end{array}$ \\
\hline $\begin{array}{l}\text { Umur pasangan (istri) } \\
\quad \leq 21 \text { tahun } \\
>21 \text { tahun }\end{array}$ & $\begin{array}{r}121 \\
1573\end{array}$ & $\begin{array}{c}7.1 \\
92.9\end{array}$ \\
\hline
\end{tabular}

Besarnya defisit berat badan pada subyek yang mengalami gangguan pertumbuhan yaitu rerata $7.46 \% \pm 5.65$, median $6.1 \%$, terendah $0.62 \%$ dan tertinggi $28.1 \%$. Ditemukan dalam analisis ini bahwa besarnya defisit berat badan berhubungan dengan pekerjaan kepala keluarga dan jumlah orang dewasa dalam rumah tangga (Tabel 3 dan 4).
Disajikan dalam Tabel 3, perbedaan defisit berat badan menurut jenis pekerjaan kepala keluarga, subyek dengan kepala keluarga tidak bekerja mengalami defisit paling tinggi dibandingkan dengan kelompok lainnya yaitu rerata defisit $9.8 \%$, pada kepala keluarga yang usaha sendiri $7.8 \%$, buruh/karyawan $7.2 \%$ dan yang termasuk pekerja bebas sebesar $5.9 \%$, dengan uji 
Kruskal Wallis perbedaan ini bermakna dengan $p=0.002$. Tampaknya kepala keluarga merupakan pencari nafkah utama karena sebagian besar pasangan kepala keluarga tidak bekerja dan subyek dari rumah tangga yang memiliki kepala keluarga tidak bekerja mengalami defisit berat badan lebih tinggi dibanding rumah tangga lainnya.

Tabel 3

Rerata defisit berat badan menurut pekerjaan kepala keluarga dan jumlah ART dewasa

\begin{tabular}{|l|c|c|}
\hline \multicolumn{1}{|c|}{ Variabel } & Rerata(\%) & Nilai p \\
\hline Pekerjaan kepala keluarga & 9.8 & 0.002 \\
Tidak bekerja & 7.8 & (Kruskal Wallis) \\
Usaha sendiri & 7.2 & \\
Buruh/karyawan & 5.9 & 0.002 \\
Pekerja bebas (tidak tentu) & & \\
\hline Jumlah orang dewasa dalam keluarga & 7.2 & (Mann Whitney) \\
1-3 orang & 8.5 & \\
$\geq 4$ orang &
\end{tabular}

Hubungan jumlah orang dewasa dalam keluarga dengan defisit berat badan disajikan dalam Tabel.4. Kelompok subyek dengan jumlah orang dewasa dalam keluarga 1-3 orang memiliki rerata defisit berat badan sebesar $7.2 \%$, berbeda dengan rerata defisit berat badan pada subyek yang memiliki jumlah orang dewasa lebih dari tiga orang yaitu rerata $8.5 \%$. Perbedaan ini bermakna dan hasil uji Mann-Whitney menunjukkan $p=0.006$. Keadaan ini merupakan petunjuk adanya masalah distribusi makanan dalam keluarga. Diungkapkan oleh Hardinsyah (6) bahwa peningkatan satu orang dewasa dalam keluarga berhubungan dengan penurunan $3.5 \%$ mutu gizi makanan keluarga. Sebaran subyek menurut umur dan rerata defisit berat badan disajikan dalam Gambar 1 . Subyek pada kelompok umur $\leq 11$ bulan mengalami defisit berat badan paling tinggi dibandingkan dengan kelompok umur lainnya, yaitu sebanyak $10.29 \%$. Sedangkan pada kelompok umur 12-23 bulan mengalami rerata defisit $7.3 \%$, kelompok usia 24-35 bulan 7.2\% dan pada kelompok umur $\geq 36$ bulan mengalami rerata defisit $7.3 \%$. 


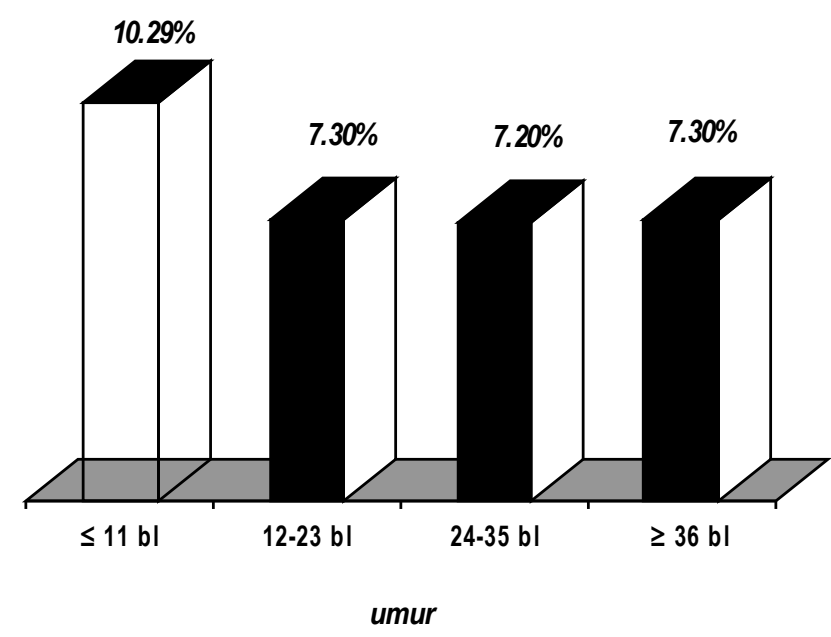

Gambar 1

Sebaran subyek menurut defisit berat badan dan kelompok umur

Setelah dipilah menurut umur dalam bulan (Gambar 2) pada kelompok subyek yang berumur kurang dari satu tahun, ternyata subyek pada kelompok umur enam bulan mengalami defisit berat badan tertinggi dibandingkan dengan kelompok umur lainnya yaitu $21.05 \%$. 


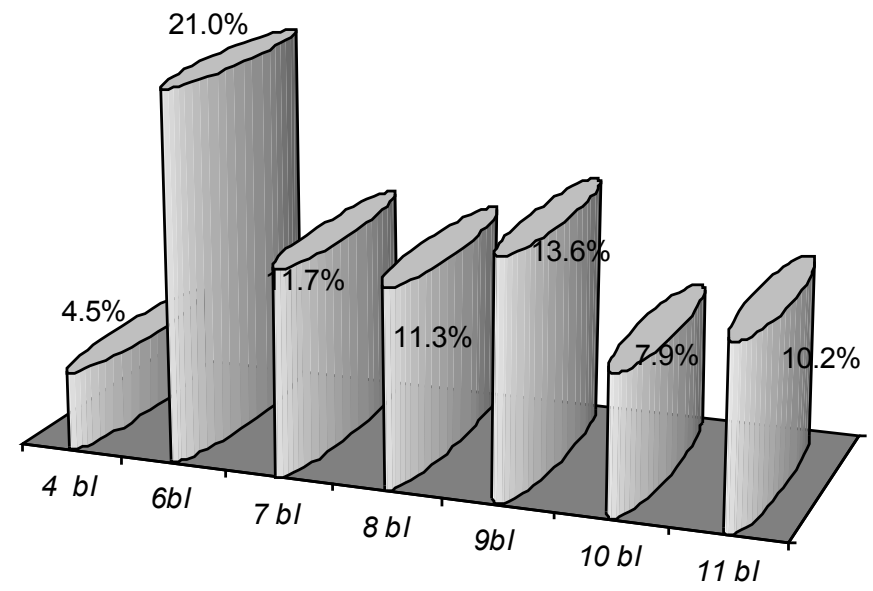

Gambar 2

Sebaran subyek menurut defisit berat badan pada kelompok umur 4-11 bulan

\section{BAHASAN}

Ditemukan dalam analisis ini bahwa $42.9 \%$ balita berada di bawah jalur pertumbuhan normal atau mengalami gangguan pertumbuhan. Subyek yang berada di bawah jalur pertumbuhan normal $46.2 \%$ berada di perkotaan dan $53.8 \%$ di pedesaan. Artinya sebagian besar subyek yang berada di bawah jalur pertumbuhan normal berada di pedesaan.

Lebih dari $50 \%$ subyek berada di pedesaan dan $62.9 \%$ termasuk katagori miskin, keadaan ini memberi petunjuk bahwa penduduk Indonesia sebagian besar berada di pedesaan dan termasuk katagori keluarga miskin. Oleh karena itu upaya perbaikan gizi sebaiknya sejalan dengan upaya perbaikan ekonomi terutama bagi masyarakat pedesaan. Karena tanpa perbaikan ekonomi upaya perbaikan gizi sering menghadapi hambatan. Misalnya makanan tambahan untuk balita gizi buruk tidak bisa sepenuhnya tepat sasaran karena dalam keluarga tersebut ada balita lain yang juga perlu makanan tambahan
Banyaknya orang dewasa dalam keluarga dan pekerjaan kepala keluarga merupakan variabel tidak langsung yang berhubungan dengan defisit berat badan, karena antara peendapatan keluarga dengan rerata defisit berat badan tidak ditemukan perbedaan bermakna. Rerata defisit berat badan pada subyek yang kaya yaitu $7.5 \%$ dan pada yang miskin $7.4 \%$. Namun demikian masalah ekonomi tampaknya menjadi masalah yang mendasar karena bila kepala keluarga tidak bekerja atau banyak orang dewasa dalam keluarga akan mengalami masalah dalam distribusi makanan sehari-hari.

Perbedaan rerata defisit berat badan juga ditemukan pada subyek yang memiliki umur ibu $\leq 21$ tahun yaitu mengalami defisit $8.5 \%$ dan pada kelompok umur $>21$ tahun sebesar $7.4 \%$, secara statistik perbedaan tersebut bermakna dengan $p=0.03$. Data di atas menunjukkan bahwa subyek yang berasal dari rumah tangga dengan umur ibu 
21 tahun atau lebih muda mengalami defisit lebih besar dibandingkan dengan subyek yang memiliki ibu yang lebih tua. Hal ini berkaitan dengan kesiapan ibu dalam memberikan pengasuhan yang akan berpengaruh terhadap kualitas pengasuhan dan dapat mengakibatkan asupan zat gizi pada subyek tidak dapat memenuhi kebutuhan sehingga terjadi gangguan pertumbuhan.

Menurut Kenneth (7) sosial budaya merupakan determinan rendahnya asupan makanan pada anak, dalam hal ini termasuk pendapatan keluarga, pendidikan , pekerjaan dan praktek budaya. Kemudian diungkapkan oleh Hartoyo (8) bahwa semakin baik praktek pengasuhan anak maka kondisi kesehatan anak menjadi semakin baik yang dicerminkan dari semakin sedikitnya jumlah hari sakit.

Keadaan ini sejalan dengan temuan Setyobudi, dkk dalam Widodo (9) bahwa menurunnya keadaan gizi lebih terlihat pada kelompok umur 6-23 bulan. Dalam analisis ini ditemukan bahwa gangguan pertumbuhan mulai terjadi pada umur empat bulan dengan defisit berat badan sebanyak $4.54 \%$. kemudian Jahari et al, (10) menyatakan bahwa growth faltering anak balita di Indonesia sudah mulai muncul pada usia antara 1-6 bulan. Peneliti lain yaitu Dewey et.al, (11) mengungkapkan bahwa growth faltering terjadi sejak usia 3-4 bulan. Menurut Jahari et.al, (10) masalah gangguan pertumbuhan pada usia dini yang terjadi di Indonesia diduga kuat berhubungan dengan banyaknya bayi yang sudah diberi makanan pendamping air susu ibu (MP-ASI) sejak usia satu bulan, bahkan sebelum usia satu bulan. Temuan Husaini et.al, (12) menunjukkan bahwa proporsi bayi yang sudah mulai diberi MP-ASI sebelum usia 1 bulan adalah $22,0 \%$. Hal senada diungkapkan Widodo,(9) di Kabupaten Wonosobo bahwa pemberian MP-ASI kepada bayi sebelum usia satu bulan mencapai $32.4 \%$.

\section{KESIMPULAN}

1 Proporsi balita yang mengalami gangguan pertumbuhan masih cukup tinggi yaitu $42.9 \%$, sebanyak $46.2 \%$ berada di perkotaan dan $53.8 \%$ di pedesaan .

2 Rerata defisit berat badan terhadap berat badan normal pada kelompok umur kurang dari satu tahun lebih tinggi dibandingkan dengan kelompok umur lainnya dan defisit tersebut terjadi sejak umur empat bulan kemudian mencapai puncaknya pada umur enam bulan (20.05\%).

\section{SARAN}

Terjadinya defisit pertumbuhan pada usia dini berdampak terhadap peningkatan proporsi balita dengan gangguan pertumbuhan, maka upaya pemantauan pertumbuhan di posyandu dan penyuluhan yang intensif terutama dalam praktek pemberian MP-ASI baik dalam segi waktu, umur berapa sebaiknya diberikan, maupun dalam segi kualitas dan kuantitas dari makanan yang diberikan merupakan suatu alternatife yang dapat dilakukan agar terjadinya hambatan pertumbuhan dapat dikendalikan sejak dini.

\section{RUJUKAN}

1. Departemen kesehatan. Gizi dalam angka sampai tahun 2002. Depkes, 2003

2. Woodhouse. $1999 \mathrm{dlm}$ Kartika V, et al 2000. Pola pemberian makan anak (618) bulan dan hubungannya dengan pertumbuhan dan perkembangan anak pada keluarga miskin dan tidak miskin .PGM.2000, 23;37-47

3. Departemen Kesehatan R.I. Pemantauan Pertumbuhan Balita. Dirjen Binkesmas- Direktorat Gizi Masyarakat. Jakarta. 2002.

4. Susanto,J.C.Gagal Tumbuh: Aspek Klinis. Prosiding Kongres Nasional 
Persagi dan temu IImiah XII. Jakarta, 810 Juli 2000

5. Survei Kesehatan Rumah Tangga vol.1.2004

6. Hardinsyah. status pekerjaan ibu dan pendapatan dlm hubungannya dengan mutu gizi makanan keluarga di daerah perkotaan media Gizi keluarga; xx(20):86-91

7. Brown. KH. Measurement of Dietary Intake..Child Survival Strategies For Research .Bellagio.Oktober 1984.

8. Hartoyo. Et.al Identifikasi factor yang berpengaruh terhadap Efektivitas Pemberian Makanan Tambahan anak Balita KEP di Kota Bogor. Media Gizi dan keluarga tahun xxv no.1;11-18, 2001.

9. Widodo, Y. Pertumbuhan bayi 0-4 bulan yang mendapat ASI Eksklusif dan ASI tidak Eksklusif. Sain Kesehatan.
Majalah Berkala Penelitian Pascasarjana IImu-ilmu Kesehatan UGM 2005;18(3):427-441

10. Jahari AB, Sandjaja, Jus'at I, Soekirman. Nutritional status of underfives in Indonesia before and during the crisis. An Analysis on anthropometric data from SUSENAS 1989-1999. WNPG VII 2000. LIPI Jakarta 2000: 93124.

11. Brown, K.H, Dewey, K., and Allen, L.. Complementary feeding of young Children in Developing Countries; A Review of Current Scientific Knowledge. World health Organization WHO.Geneva 1998

12. Husaini, M.A.Stevenhuysen, G.P, Husaini, Y.K, Widodo, Y.dan Triwinarto, A.. Gizi ibu dan bayi. Puslitbang Gizi .laporan yang tdk dipublikasikan 1997. 